\title{
ANALISIS KESIAPSIAGAAN SISWA DALAM MENGHADAPI BENCANA KEKERINGAN MELALUI MEDIA BOOKLET
}

\author{
Fajar Wulandari \\ STKIP Singkawang \\ e-mail: fajarwulandari3@gmail.com
}

\begin{abstract}
This study aims to determine the preparedness of high school students in facing drought in Singkawang City, with the help of preparedness booklet learning media. This study uses experiment method. The Quantitative data were analyzed using experimental methods and percentage techniques; preparedness and documentation questionnaires were used for data collection. The data analysis technique used was anava and anava further test. The prerequisite test used is the normality test and homogeneity test. Hypothesis test results show a comparison of probability values $>0.05$ then $\mathrm{Ho}_{\mathrm{o}}$ is accepted and probability value $<0.05$, then $\mathrm{Ho}$ is rejected and if the value of sig $(2$-tailed) $0,000<0.05$ then $\mathrm{Ho}$ is rejected which means the provision of learning media Booklet affect the preparedness of students at SMAN Kota Singkawang. The results of student preparedness in the face of disasters indicate that there are students who are unprepared and almost ready for $33.33 \%$ who are not ready to face drought natural disasters. But after being given learning with the help of booklet media, it was found that 99.98\% of students had understood how to act on drought disasters. The conclusion in this study is that booklet learning media is effective in influencing and improving the results of the students' preparedness in the face of natural disasters in Singkawang City.
\end{abstract}

Keywords: Learning Media, Booklet, Preparedness, Drought, Natural Disasters.

\begin{abstract}
Abstrak: Penelitian ini bertujuan untuk mengetahui kesiapsiagaan siswa SMA dalam menghadapi bencana kekeringan di Kota Singkawang dengan dibantu media pembelajaran booklet kesiapsiagaan. Penelitian ini menggunakan metode penelitian eksperimen. Subjek penelitian ini adalah siswa kelas XI SMA di Kota Singkawang, di SMA Negeri 1 Kota Singkawang. Analisis data secara kuantitatif dengan metode eksperimen dan teknik persentase, pengumpulan data dengan menggunakan angket kesiapsiagaan dan dokumentasi. Teknik analisis data yang digunakan adalah anava dan uji lanjut anava. Uji prasyarat yang digunakan yaitu uji normalitas dan uji homogenitas. Hasil uji hipotesis menunjukkan perbandingan nilai probabilitas $>0,05$ maka Ho diterima dan nilai probabilitas $<0,05$ maka Ho ditolak dan jika nilai sig(2-tailed) $0,000<0,05$ maka Ho ditolak yang berarti pemberian media pembelajaran Booklet dalam penelitian telah mempengaruhi kesiapsiagaan siswa SMAN Kota Singkawang. Hasil kesiapsiagaan siswa dalam menghadapi bencana menunjukkan terdapat siswa yang kurang siap dan hampir siap sebesar 33,33\% yang kurang siap dalam menghadapi bencana alam kekeringan. Namun setelah diberikan pembelajaran dengan bantuan media booklet didapatkan 99,98\% siswa yang telah paham dalam bertindak mengahdapi bencana alam kekeringan. Kesimpulan dalam penelitian ini adalah media pembelajaran Booklet efektif dalam mempengaruhi dan meningkatkan hasil kesiapsiagaan siswa dalam menghadapi bencana alam di Kota Singkawang.
\end{abstract}

Kata kunci: Media Pembelajaran, Booklet, Kesiapsiagaan, Kekeringan, Bencana Alam. 


\section{PENDAHULUAN}

Kesiapsiagaan, merupakan tindakan yang wajib dimiliki oleh setiap orang karena keadaan alam yang tidak dapat diprediksi dengan jelas, sehingga bencana alam dapat terjadi kapan saja. Di daerah Kalimantan barat yang berada di dataran rendah dan memiliki ratusan sungai yang mengalir sepanjang Lembah Kapuas serta Laut Natuna / Selat Karimata. Dataran ini juga merupakan dataran rawa bercampur gambut dan hutan mangrove. Keberagaman dataran yang ada di Kalimantan Barat memberikan potensi yang baik bagi pertumbuhan di daerah-daerah, namum terdapat pula ancaman bencana yang dapat terjadi. Kalimantan Barat yang berada pada zona tinggi dan sedang berdasarkan indeks resiko bencana kabupaten/kota (IRBI,2013).

Kota Singkawang yang masuk ke dalam zona tinggi dengan (skor 178) berdasarkan indeks resiko bencana kabupaten/kota (IRBI,2013). Sekolah yang merupakan sarana dalam mentransfer ilmu pengetahuan., sehingga terdapat upaya dari pembelajaran yang diterima peserta didik guna kesiapsiagaan yang baik pada peserta didik dalam mengahadapi bencana alam yang berpotensi terjadi di daerahnya. Kesiapsiagaan adalah tindakan yang dilakukan dalam rangka mengantisipasi suatu bencana untuk memastikan bahwa tindakan yang dilakukan dapat dilaksanakan secara tepat dan efektif pada saat dan setelah terjadi bencana (Krisna S. Pribadi, 2008). Yusuf Hadi Miarso, mengatakan bahwa media adalah segala sesuatu yang dapat digunakan untuk merangsang pikiran, perasaan, perhatian dan kemauan siswa sehingga dapat mendorong terjadinya proses belajar pada diri pembelajar (Hujair AH Sanaky,2013:3-4).

Media pembelajaran mempunyai kedudukan yang penting, dalam proses belajar mengajar, karena dalam kegiatan di kelas tentunya terjadi interaksi penyampaian materi pembelajaran antara guru kepada siswa, sehingga akan lebih mudah penyampaian tersebut bila menggunakan perantara yaitu dapat berupa media. Booklet berisikan informasi-informasi penting, suatu booklet isinya harus jelas, tegas, mudah dimengerti dan akan lebih menarik jika booklet tersebut disertai dengan gambar. Bentuknya yang kecil menjadikan booklet mudah dibawa. Selain itu booklet yang berisikan tentang informasi-informasi penting disertai gambar ilustrasi memudahkan peserta didik menggunakan dalam proses pembelajaran. Booklet bersifat informatif, desainnya yang menarik dapat menimbulkan rasa ingin tahu, sehingga peserta didik bisa memahami dengan mudah apa yang disampaikan dalam proses pembelajaran.

Bencana alam adalah bencana yang diakibatkan oleh peristiwa atau serangkaian peristiwa yang disebabkan oleh antara lain: gempa bumi, tsunami, gunung meletus, banjir, 
kekeringan, angin topan/puting beliung, dan tanah longsor (UU tentang Penanggulangan bencana Pasal 1). Kekeringan menurut BAKORNAS PB (Pengenalan Karakteristik Bencana dan Upaya Mitigasinya di Indonesia, 2007) Kekeringan adalah hubungan antara ketersediaan air dan yang jauh di bawah air baik untuk kebutuhan hidup, pertanian, kegiatan ekonomi dan lingkungan. Bencana kekeringan adalah situasi atau kondisi dimana kekurangan air bersih dalam waktu yang lama sehingga menimbulkan kerugian secara material kepada masyarakat. Penelitian ini menggunakan angket untuk memperoleh data dari siswa dengan acuan dari LIPI UNESCO/ISRD 2006 untuk indeks guru dan siswa diperoleh dari gabungan indeks pengetahuan dan sikap terhadap bencana, rencana penyelamatan dalam kondisi darurat bencana, indeks peringatan dan indeks mobilisasi sumberdaya. Parameter kesiapsiagaan di atas akan dijadikan sebagai kategori tingkat keiapsiagaan siswa dalam menghadapi bencana. Tingkat kesiapsiagaan siswa dalam penelitian ini dikategorikan menjadi lima, sebagai berikut:

Tabel 1. Ukuran Kesiapsiagaan Bencana Kekeringan

\begin{tabular}{ccc}
\hline No & Nilai Indeks & Kategori \\
\hline 1 & $80-100$ & Sangat Siap \\
\hline 2 & $67-79$ & Siap \\
\hline 3 & $55-64$ & Hampir siap \\
\hline 4 & $40-54$ & Kurang Siap \\
\hline 5 & $<40(0-39)$ & Belum Siap \\
\hline
\end{tabular}

Sumber: LIPI_UNESCO/ISRD, 2006

Perubahan iklim yang terjadi akibat pamanasan global telah memberikan dampak kepada musim di Indonesia, sehingga musim penghujan dan musim kemarau yang terjadi belum dapat diantisipasi secara baik oleh masyarakat khususnya pada komunitas sekolah. Dampak yang muncul akibat perubahan musim tersebut, salah satunya yaitu bencana alam dalam hal ini bencana kekeringan yang terjadi di Kota Singkawang. Musim kemarau yang terjadi berkepanjangan yang melebihi masa normalnya, memberikan pengaruh yang tidak baik bagi kesehatan.

Dengan demikian penelitian ini dilakukan guna bertujuan untuk mengetahui dan mengantisipasi kesiapsiagaan siswa sma dalam menghadapi bencana kekeringan di kota singkawang, dengan berbantu media pembelajaran booklet kesiapsiagaan. media pembelajaran bookletmerupakan alternatif bagi siswa di SMA Negeri 1 untuk penunjang pembelajaran geografi khusunya pada pendidikan kebencanaan, dengan mengetahui perbedaan hasil belajar dan respon siswa terhadap penerapan media pembelajaran booklet materi mitigasi dan adaptasi bencana alam. Sehingga diharapkan setelah diberikan pembelajaran tentang kesiapsiagaan 
menghadapi bencana kekeringan masyarakat khususnya siswa dapat sigap dan siap dalam menghadapi bencana kekeringan.

\section{METODE}

Penelitian ini untuk mengetahui efektivitas dari penggunaan media booklet kesiapsiagaan bencana kekeringan, sehingga dapat diketahui kesiapsiagaan siswa dalam menghadapi bencana. Penelitian ini menggunakan One Group Pretest Posttest design yaitu desain yang terdapat pretest sebelum diberi perlakuan dan posttest setelah diberikan perlakuan, sehingga data yang diperoleh lebih akurat. Pengambilan data dengan menggunakan angket penelitian, kemudian media booklet dianalisis oleh para ahli media sehingga layak untuk disebarkan kepada siswa dan melakukan penelitian untuk memperoleh data yang akan dianalisis secara kuantitatif dengan mengisi skor pada angket.

Pada penelitian ini dilakukan uji prasyarat yaitu uji normalitas dengan menggunakan metode Kolmogorov-Smirnov dan uji hipotesis (uji t) dengan bantuan program SPSS 21. Data penelitian yang diperoleh dari siswa kemudian dianalisis dengan mengguankan rumus gabungan parameter kesiapsiagaan, seperti di bawah ini:

\begin{tabular}{|c|l|c|c|c|c|c|c|}
\hline \multirow{2}{*}{ No } & Komponen & \multicolumn{5}{|c|}{ Indeks Parameter Kesiapsiagan } \\
\cline { 3 - 8 } & Komunitas Sckolah & KA & PS & EP & WS & RMC & JUML.AH \\
\hline 1. & Siswa (S3) & n & - & $n$ & $n$ & $n$ & $n$ \\
\hline
\end{tabular}

\footnotetext{
Indeks gabungan $-\left(\frac{\text { bobot ril KA }}{\text { bobot maksimal }} \mathrm{x}\right.$ indeks KA $)+\left(\frac{\text { bobot rit EP }}{\text { bobot maksimal }} \mathrm{x}\right.$

indeks EP $)+\left(\frac{\text { bobot ril ws }}{\text { bobot makssimal }} \mathrm{x}\right.$ indeks WS $)+\left(\frac{\text { bobot ril } R M C}{\text { bobot maksimal }} x\right.$

indeks RMC)
}

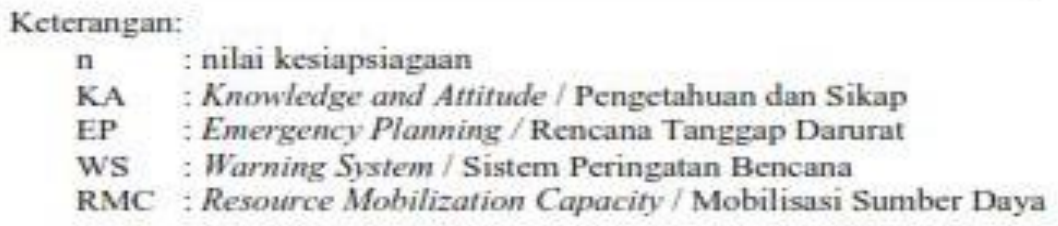

Gambar 1. Rumus Gabungan Parameter Kesiapsiagaan

Analisis prasyarat menggunakan uji normalitas dan uji $\mathrm{t}$ kemudian dilanjutkan dengan menghitung data menggunakan rumus parameter kesiapsiagaan yang dianalisis dan dideskripsikan setiap parameter. 


\section{HASIL DAN PEMBAHASAN}

Hasil pada penelitian ini menampilkan laporan kemajuan penelitian dengan proses pembelajaran menggunakan media booklet menghadapi bencana alam. Penelitian yang dilakukan adalah untuk mengetahui kesiapsiapsiagaan siswa di SMAN 1 Singkawang dengan bantuan media booklet sebelum dan setelah diberikan media booklet, sehingga dapat diketahui kesiapsiagaan siswa dalam menghadapi bencana kekeringan. Namun, sebelum media booklet digunakan dalam penelitian ini, media booklet tersebut telah kami validasi terlebih dahulu kepada ahli media dan materi, sehingga media booklet tersebut layak untuk digunakan dalam penelitian.

Uji normalitas dilakukan bertujuan untuk mengetahui kriteria data jika probabilitas $>0,05$ maka data berdistribusi normal sedangkan bila data memiliki probabilitas $<0,05$ maka data tidak berdistribusi normal. Uji normalitas data menggunakan Kolmogorov-Smirnov dengan bantuan SPSS 21.

Tabel 2. Hasil Uji Normalitas

\begin{tabular}{ccc}
\hline Variabel & $\begin{array}{l}\text { Kolmogorov- } \\
\text { Smirnov Z }\end{array}$ & Asymp. Sig.(2-tailed) \\
\hline $\begin{array}{c}\text { Kesiapsiagaan Siswa } \\
\text { Sebelum diberikan Media }\end{array}$ & 1,340 & 0,055 \\
\hline $\begin{array}{c}\text { Kesiapsiagaan Siswa } \\
\text { Sesudah diberikan Media }\end{array}$ & 0,723 & 0,672 \\
\hline
\end{tabular}

Hasil pengujian normalitas dengan menggunakan metode Kolmogorov- Smirnov, diketahui bahwa kesiapsiagaan siswa SMAN 1 Singkawang sebelum diberikan media pembelajaran booklet nilai sebesar 1,340 dengan $\mathrm{p}=0,055$ dan sesudah diberikan media kesiapsiagaan siswa diperoleh nilai normalitas sebesar 0,723 dengan $\mathrm{p}=0,672$ sehingga hasil perhitungan normalitas menunjukkan bahwa nilai sig $>0,05$; maka untuk data tingkat kesiapsiagaan siswa SMAN 1 Singkawang dalam menghadapi bencana alam di Kota Singkawang berdistribusi normal.

Uji Paired sample-t Test pada penelitian ini ditujukan untuk menguji perbedaan dari sampel yang mengalami dua perlakuan. Uji t pada penelitian ini digunakan untuk mengetahui pengaruh dari variable independen secara parsial terhadap variable dependen, apakah terdapat pengaruh setelah diberikan dua perlakuan, dengan menggunakan bantuan aplikasi SPSS 21. Kriteria jika nilai probabilitas $<0,05$ maka terdapat pengaruh, sedangkan jika nilai probabilitas $>0,05$ maka tidak terdapat pengaruh kesiapsiagaan siswa dalam menghadapi bencana alam sebelum dan sesudah diberikan perlakuan dalam proses pembelajaran dengan menggunakan media Booklet.. Uji hipotesis pada penelitian ini menggunakan uji beda paired 
sample t- test dengan menggunakan bantuan SPSS 21, tujuannya untuk mengetahuipengaruh penggunaan media pembelajaran Booklet terhadap kesiapsiagaan siswa dalam menghadapi bencana alam di Kota Singkawang, maka diperoleh hasil sebagai berikut:

Tabel 3. Uji t

\begin{tabular}{|c|c|c|c|c|c|c|c|c|c|}
\hline \multicolumn{10}{|c|}{ Paired Sample Test } \\
\hline & & \multicolumn{5}{|c|}{ Paired } & \multirow{3}{*}{$\mathrm{t}$} & \multirow{3}{*}{ df } & \multirow{3}{*}{$\begin{array}{l}\text { Sig. (2- } \\
\text { tailed) }\end{array}$} \\
\hline & & \multirow[t]{2}{*}{ Mean } & \multirow[t]{2}{*}{$\begin{array}{c}\text { Std. } \\
\text { Deviation }\end{array}$} & \multirow[t]{2}{*}{$\begin{array}{l}\text { Std. Error } \\
\text { Mean }\end{array}$} & \multicolumn{2}{|c|}{$\begin{array}{c}95 \% \\
\text { Confidence } \\
\text { Interval of the }\end{array}$} & & & \\
\hline & & & & & Lower & Upper & & & \\
\hline $\begin{array}{l}\text { Pair } \\
1\end{array}$ & $\begin{array}{l}\text { Sebelum - } \\
\text { Sesudah }\end{array}$ & 12.333 & 8.431 & 1.622 & -15.668 & -8.998 & -7.601 & 6 & .000 \\
\hline
\end{tabular}

Hasil analisis uji t pada Tabel 3 di atas menjelaskan bahwa perbandingan nilai probabilitas $>0,05$ maka Ho diterima dan nilai probabilitas $<0,05$ maka Ho ditolak dan jika nilai sig(2-tailed) $0,000<0,05$ maka Ho ditolak yang berarti pemberian media pembelajaran Booklet dalam penelitian telah mempengaruhi kesiapsiagaan siswa SMAN 1 dalam menghadapi bencana alam di Kota Singkawang. Output mean sebesar 12,333 yaitu selisih dari rata- rata kesiapsiagaan siswa sebelum dan setelah diberikan media Booklet

Analisis data penelitian ini untuk mengetahui kesiapsiagaan siswa sebelum dan setelah diberikan media Booklet. Hasil analisis data dijabarkan melalui analisa deskriptif kuantitatif dengan menggunakan indeks kesiapsiagaan siswa dalam menghadapi bencana alam.

Tabel 4. Kesiapsiagaan Siswa SMAN 1 Singkawang Sebelum diberikan Media Booklet

\begin{tabular}{cccc}
\hline & & Nilai & \\
No & Indeks \& Nilai Kesiapsiagaan & Sebelum & Persentase (\%) \\
\hline 1. & Sangat Siap (80-100) & 0 & 0 \\
\hline 2. & Siap (65-79) & 18 & 66,6667 \\
\hline 3. & Hampir Siap (55-64) & 5 & 18,5185 \\
\hline 4. & Kurang Siap (40-54) & 4 & 14,8148 \\
\hline 5. & Belum Siap (<40) & 0 & 0 \\
\hline & Jumlah Responden (Siswa) & 27 & 100 \\
\hline
\end{tabular}

Berdasarkan tabel 4. Nilai indeks kesiapsiagaan siswa SMAN 1 Singkawang dalam menghadapi bencana Sebelum diberikan Media Booklet untuk siswa yang termasuk dalam kategori "Sangat Siap" sebanyak 4 orang (14,286\%), "Siap" sebanyak 7 orang (25\%), "Hampir Siap" sebanyak 9 orang (32,143\%), "Kurang Siap" sebanyak 4 orang (14,286\%) dan "Belum Siap" sebanyak 4 orang $(14,286 \%)$. 
Tabel 5. Kesiapsiagaan Siswa SMAN 1 Singkawang Setelah diberikan Media Booklet

\begin{tabular}{cccc}
\hline No & Indeks \& Nilai Kesiapsiagaan & Nilai Setelah & Persentase $(\%)$ \\
\hline 1. & Sangat Siap (80-100) & 15 & 55,7 \\
\hline 2. & Siap (65-79) & 12 & 44,3 \\
\hline 3. & Hampir Siap (55-64) & 0 & 0 \\
\hline 4. & Kurang Siap (40-54) & 0 & 0 \\
\hline 5. & Belum Siap (<40) & 0 & 0 \\
\hline & Jumlah Responden (Siswa) & 27 & 100 \\
\hline
\end{tabular}

Hasil perhitungan berdasarkan tabel 5. Nilai indeks Kesiapsiagaan siswa SMAN 2 Singkawang dalam menghadapi bencana setelah diberikan perlakuan yaitu dengan media Booklet diketahui mengalami peningkatan, untuk siswa yang termasuk dalam kategori "Sangat Siap" sebanyak 15 orang (55,66\%), "Siap" sebanyak 12 orang (44,44\%), dan untuk kategori "Hampir Siap", "Kurang Siap" dan "Belum Siap" sebanyak 0 orang $(0 \%)$.

Indeks gabungan yaitu hasil nilai dari gabungan seluruh parameter kesiapsiagaan siswa dalam menghadapi bencana alam, yang kemudian dihitung dengan menggunakan rumus indeks gabungan artinya masing- masing parameter memiliki bobot yang berbeda. Peneliti menggunakan perhitungan indeks gabungan kesiapsiagaan LIPI-UNESCO, 2006 sebagai berikut:

Tabel 6. Indeks gabungan kesiapsiagaan siswa SMAN 1 sebelum diberikan media booklet

\begin{tabular}{cccccccc}
\hline \multirow{2}{*}{ No } & $\begin{array}{l}\text { Komponen } \\
\text { Komunitas } \\
\text { Sekolah }\end{array}$ & KA & PS & EP & WS & RMC & Jumlah \\
\cline { 2 - 5 } & Siswa (S3) & 66 & - & 65 & 63 & 55 & 249 \\
\hline Indeks Gabungan siswa (S3) & $=66^{*} 0,27+65^{*} 0,26+63^{*} 0,25+55^{*} 0,22$ \\
& $=17,82+16,9+15,75+12,1$ \\
& $=62,57$ (Hampir Siap)
\end{tabular}

Hasil perhitungan indeks gabungan kesiapsiagaan siswa di atas menunjukkan bahwa kesiapsiagaan siswa SMAN 1 Singkawang dalam menghadapi bencana alam sebelum diberikan media booklet adalah 62,57 termasuk dalam kategori "hampir siap".

Tabel 7. Indeks gabungan kesiapsiagaan siswa SMAN 1 setelah diberikan media booklet

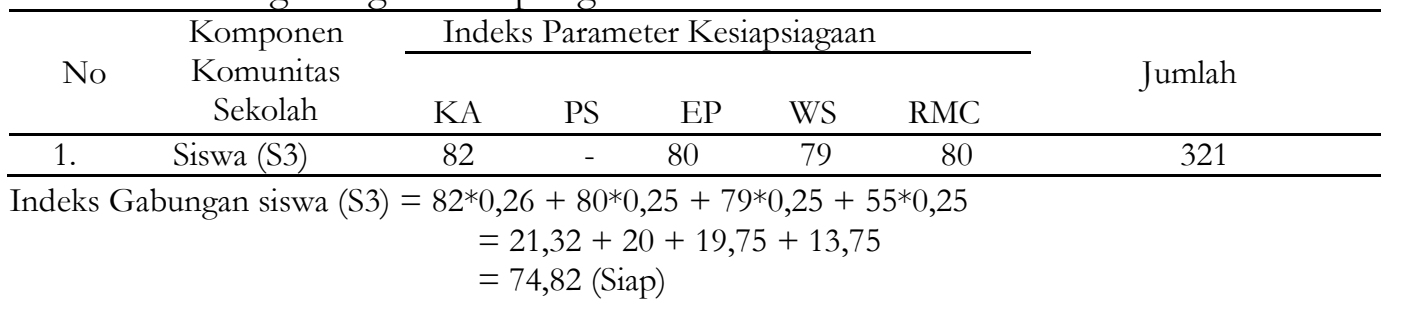


Hasil perhitungan indeks gabungan kesiapsiagaan siswa di atas menunjukkan bahwa kesiapsiagaan siswa SMAN 1 Singkawang dalam menghadapi bencana alam setelah diberikan media booklet adalah 74,82 termasuk dalam kategori "Siap".

Media booklet yang digunakan dalam penelitian ini membahas materi kesiapsiagaan, kemudian media booklet dilakukan validasi oleh beberapa ahli yaitu diantaranya validasi oleh ahli media, ahli materi dan praktisi lapangan yaitu guru geografi. Media booklet yang valid kemudian digunakan dalam penelitian. Materi kesiapsiagaan yang dibahas dalam media booklet ini menjelaskan bencana alam yang telah terjadi di Kota Singkawang, sehingga siswa dalam penelitian ini diharapkan memiliki kesiapsiagaan dalam menghadapi bencana alam di Kota Singkawang. Tujuan dari validasi kepada para ahli media yaitu untuk mengetahui kelayakan dari media booklet kesiapsiagaan siswa dalam menghadapi bencana alam dan penelitian dilakukan di SMAN 1 Singkawang, SMAN 2 Singkawang dan SMAN 6 Singkawang pada saat yang berbeda, setelah diperoleh data dari siswa yang diberikan perlakuan dengan media booklet peneliti melakukan analisis data untuk menjawab rumusan masalah dalam penelitian ini Penelitian diawali dengan menyebarkan instrument penelitian (angket penelitian kesiapsiagaan) kepada siswa di kelas. Siswa diberikan waktu untuk menjawab instrument yang telah disebar kemudian setelah selesai angket yang sebelumnya diisi oleh siswa dikumpulkan kembali. Dilanjutkan dengan proses belajar mengajar di kelas terjadi interaksi antara peneliti dan siswa dengan bantuan media pembelajaran Booklet pada tema pembelajaran yang membahas tentang bencana alam yang terjadi di Kota Singkawang dan kesiapsiagaan yang wajib siswa miliki agar tercegah dari kerugian apabila bencana tersebut kembali terjadi.

Berdasarkan Indeks Resiko Bencana Kabupaten/Kota (IRBI, 2013) Kota Singkawang termasuk dalam zona tinggi dengan skor 178. Data tersebut menegaskan resiko dan ancaman bencana di Kota Singkawang tinggi sehingga diperlukannya pengetahuan dan sikap kesiapsiagaan dalam menghadapi bencana. Komunitas sekolah, dalam penelitian ini menjadikan siswa sebagai objek utama untuk ditingkatkan kesiapsiagaannya.

\section{PENUTUP}

Kesimpulan dalam penelitian ini adalah media pembelajaran booklet layak digunakan dalam proses pembelajaran di kelas. Media pembelajaran booklet terbukti dapat meningkatkan kesiapsiagaan siswa dalam menghadapi bencana alam di Kota Singkawang. Hasil Penelitian Menunjukkan Bahwa Pembelajaran Yang Menggunakan Media Booklet adalah "Sangat Siap". sehingga diharapkan agar data memudahkan pembelajaran kebencaan dapat menggunakan 
media inovatif dengan demikian siswa dapat lebihmudah memahami dalam pembelajaran khususnya pelajaran geografi (kebencanaan)

\section{REFERENSI}

Akbar, S. 2013. Instrumen Perangkat Pembelajaran. Bandung: Remaja Rosdakarya Offset Bakornas Penanggulangan Bencana. 2007. Pengenalan Karakteristik Bencana dan Upaya Mitigasinya di Indonesia. Direktorat Mitigasi Lahar BAKORNAS PB: Jakarta.

Kurniawan Lilik, Sugeng Triutomo, Ridwan Yunus, Mohd. Robi Amri, Arezka Ari Hantyanto. 2013. IRBI (Indeks Resiko Bencana Indonesia). BNPB

Nana Sudjana dan Ahmad Riva'i. (2011). Media Pengajaran. Bandung: Sinar Baru Algensindo.

Nugroho, Kharisma, (2009). Preparedness Assessment Tools For Indonesia (PASTI). Jakarta: Humanitarian Forum Indonesia dan MDMC.

Putra, N. (2011). Research \& Development Penelitian dan Pengembangan: Suatu Pengantar. Jakarta: PT Raja Grafindo Persada.

Pribadi, S. Krishna. 2008. Buku Pegangan Guru : Pendidikan Siaga Bencana. Bandung: Pusat Mitigasi Bencana - Institut Teknologi Bandung.

Rendra Oxtora. 2016. Kalbar fokuskan kebakaran gambut. http://kalbar.antaranews.com/berita/342933/kalbar-fokuskan-pencegahan kebakaran-gambut

Ruswandi Dody, dkk. 2013. IRBI Indek Resiko Bencana Indonesia. BNPB.

Sanaky, AH. Hujair. 2013. Media Pembelajaran Interaktif-Inovatif. Yogyakarta, Penerbit Kaukabata Dipantara.

Sugiyono. 2013. Metode Penelitian Kuantitatif, Kualitatif dan R\&D. Bandung. Penerbit Alfabeta Bandung.

Sujadi, E. (2017). Penerapan Pendidikan Karakter Cerdas Format Kelompok untuk Meningkatkan Nilai Kejujuran Mahasiswa Bimbingan Konseling Islam (BKI) Institut Agama Islam Negeri (IAIN) Kerinci. Tarbawi : Jurnal Ilmu Pendidikan, 13(1), 97-108

Sujadi, E., \& Wahab, M. (2018). Strategi Coping Korban Bullying. Tarbawi : Jurnal Ilmu Pendidikan, 13(2), 21-32.

Sopaheluwakan Jan, dkk. 2006. Kajian Kesiapsiagaan Masyarakat dalam Mengantisipasi Bencana Gempa Bumi dan Tsunami. Lipi - Unesco/Isdr.

Trianto. (2009). Mendesain Model Pembelajaran Inovatif-Progresif:Konsep, Landasan, dan Implementasinya pada Kurikulum Tingkat Satuan Pendidikan (KTSP).Jakarta: Kencana. 
Wardhani, P. (2012). Pengembangan Buku Cerita Bergambar Berbasis Konservasi Lingkungan untuk Pemelajaran Membaca Siswa SD Kelas Rendah.Skripsi. Semarang: Universitas Negeri Semarang.

Undang-Undang Republik Indonesia Nomor 24 Tahun 2007 Tentang Penanggulangan Bencana 